\title{
Effect of carbon-rich-waste addition as co-substrate on the performance and stability of anaerobic digestion of abattoir wastewater without agitation
}

\author{
Abrha Mulu Hailu ${ }^{1,2^{*}} \mathbb{0}$, Seyoum Leta Asfaw ${ }^{1}$ and Tenalem Ayenew Tegaye ${ }^{3}$
}

\begin{abstract}
Multiple wastes' co-digestion is one of the alternatives for improved anaerobic digestion (AD) process of industrial and municipal wastes. The present work investigated the influence of fruit-vegetable solid waste (FVW) addition as a co-substrate on the performance of AD of abattoir wastewater (AWW). The co-digestion was done at a lab-scalebased experiment under mesophilic condition using a two-phase anaerobic sequencing batch reactor without agitation. It was tested at different mixing ratios (100\%AWW; 75\%AWW:25\%FVW; 50\%AWW:50\%FVW; 25\%AWW:75\%FVW; $100 \% \mathrm{FVW}$ ) with the intention of looking for the best mixing ratio with the best performance. It was fed on a semicontinuous basis and operated for 18 days (d) total retention time (HRT): 3 days for the acidogenesis reactor and 15 days for methanogenesis reactor. The addition of FVW enhanced biogas yield and VS removal by $70.26 \%$ and $57.11 \%$, respectively, at optimum mixing ratio. Moreover, to some extent improvement of AD process stability verified by the decreased TVFA:TAlk ratio and free ammonia nitrogen was observed upon progressive addition of FVW. Finally, this co-digestion process should further be studied for its performance at different HRTs with agitation.
\end{abstract}

Keywords: Abattoir wastewater, Biogas, Fruits-vegetables waste, Mixing ratios, Phased anaerobic co-digestion

\section{Introduction}

Presently, more than 14 abattoir industries are operating only in the capital of Ethiopia, Addis Ababa city and its peripheries. Those industries are polluting downstream surface waters and causing an adverse impact on receiving surface water due to the discharge of unsafe abattoir wastewater (AWW) (Mulu et al. 2015). Likewise, the fruits-vegetables solid waste (FVW) management is also one of the challenges among municipal solid waste managements in the city. It is generated in substantial quantities in the fruits and vegetables central market of the city. It constitutes about $4.2 \%$ (273 tonnes per day) of the total solid waste generated in the city (Tesema

\footnotetext{
*Correspondence: chem.mulu@gmail.com; abrha.mulu@aau.edu.et ${ }^{1}$ Centre for Environmental Science, Addis Ababa University, Addis Ababa, Ethiopia
}

Full list of author information is available at the end of the article
2010;Gebreeyessus and Demissie 2013). It creates a nuisance to residents proximate the market and disposal site due to its high biodegradability and inefficient collection system.

Previously, the anaerobic mono-digestion abattoirs waste was studied in single-phase anaerobic reactors. These include abattoir wastewater (AWW) (Padillagasca et al. 2011; Jabari et al. 2016); mixture of cattle and pigs AWW (Stets et al. 2014); poultry AWW (Delforno et al. 2017); and cattle AWW (Worku and Leta 2017; Musa et al. 2018). Nonetheless, AD of single substrates presents some limitations linked to substrate characteristics. The limitations associated with the AD of abattoir wastes are volatile fatty acids' accumulation and/or ammonia inhibitions. But simultaneous digestion of two or more substrates (co-digestion) is one means of feasible option to overcome such drawbacks (Mata-Alvarez et al. 
Table 1 Performance of anaerobic co-digestion abattoir wastes with different substrates

\begin{tabular}{|c|c|c|c|}
\hline Co-digested substrate(s) & Operating conditions & Improvement & Reference \\
\hline $\begin{array}{l}\text { Cattle slurry (manure) with fruit-veg- } \\
\text { etable waste (FVW) and chicken } \\
\text { manure }\end{array}$ & $\begin{array}{l}\text { Continuous stirred tank reactor (CSTR); } \\
\text { mesophilic temp; } 21 \text { days HRT; OLR } \\
\text { 3.19-5.01 kg VS/m³ day }\end{array}$ & $20-50 \% \mathrm{CH}_{4}$ yield increment & Callaghana et al. (2002) \\
\hline $\begin{array}{l}\text { Manure, solid abattoir wastes (cattle } \\
\text { and swine), and FVW }\end{array}$ & $\begin{array}{l}\text { Semi-continuous stirred reactor; } \\
\text { mesophilic temp; up to } 1.3 \mathrm{~kg} \mathrm{VS} / \mathrm{m}^{3} \\
\text { day OLRT; } 30 \text { days HRT }\end{array}$ & By factory 5 biogas yield increment & Alvarez and Lidén (2008) \\
\hline Rendering and abattoir solid wastes & $\begin{array}{l}\text { CSTR; Lab-scale; semi-continuously } \\
\text { fed; } 35 \text { and } 55^{\circ} \mathrm{C} \text { temp; } 1.0 \text { and } 1.5 \\
\text { kg VS/m } / \mathrm{m}^{3} \text { day OLRs; } 50 \text { days HRT }\end{array}$ & $0.262-0.572 \mathrm{~m}^{3} \mathrm{CH}_{4} / \mathrm{kg}$ VS added & Bayr et al. (2012) \\
\hline $\begin{array}{l}\text { Solid cattle abattoir wastes (ASW), } \\
\text { manure, various crops, and munici- } \\
\text { pal solid wastes (MSW) }\end{array}$ & $\begin{array}{l}\text { Anaerobic batch experiment; thermo- } \\
\text { philic }\left(55^{\circ} \mathrm{C}\right) \text { for } 70 \text { days: different } \\
\text { mixture ratios }\end{array}$ & $\begin{array}{l}31 \% \text { increase of the expected } \mathrm{CH}_{4} \\
\text { yield at equal mixture of each } \\
\text { substrates }\end{array}$ & Pagés-Díaz et al. (2014); \\
\hline $\begin{array}{l}\text { Pig abattoir wastes with sewage } \\
\text { sludge }\end{array}$ & $\begin{array}{l}\text { Batch and semi-continuous experi- } \\
\text { ments; } 35^{\circ} \mathrm{C} \text { Temp }\end{array}$ & $\begin{array}{l}>50 \% \text { the methane yield exceeding } \\
\text { than mono-digestion }\end{array}$ & Borowski and Kubacki (2015) \\
\hline $\begin{array}{l}\text { ASW with manure, various crops, and } \\
\text { MSW in different mix ratios }\end{array}$ & $\begin{array}{l}\text { Semi-continuous and batch operation } \\
\text { mode }\end{array}$ & $\begin{array}{l}70-75 \% \text { methane yield exceeding } \\
\text { than mono-digestion }\end{array}$ & Pagés-Díaz et al. (2015) \\
\hline $\begin{array}{l}\text { Pasteurized abattoir waste, pig slurry } \\
\text { (manure) and glycerine }\end{array}$ & $\begin{array}{l}\text { CSTR; mesophilic temp; } 21-33 \text { days } \\
\text { HRT; } 0.8-3.2 \mathrm{~kg} \text { COD } / \mathrm{m}^{3} \text { day OLR }\end{array}$ & $153 \% \mathrm{CH}_{4}$ yield increment & (Rodríguez-Abalde et al. 2017) \\
\hline $\begin{array}{l}\text { Food waste (FW) with abattoir waste } \\
\text { (AW) and sewage sludge(MSS) }\end{array}$ & $\begin{array}{l}\text { Lab-scale reactor; semi-continuous } \\
\text { operation; mesophilic conditions; } \\
\text { 30 SRT }\end{array}$ & $\begin{array}{l}0.63 \mathrm{~m}^{3} \mathrm{CH}_{4} / \mathrm{kg} \text { VS fed for (FW+ AW) } \\
0.46 \mathrm{~m}^{3} \mathrm{CH}_{4} / \mathrm{kg} \text { VS fed for (FW + MSS) }\end{array}$ & Borowski et al. (2018) \\
\hline $\begin{array}{l}\text { Pig abattoir by-products ( } 5 \% \text { pork by- } \\
\text { products mixed with pig manure) }\end{array}$ & $\begin{array}{l}\text { CSTR; batch and semi-continuously } \\
\text { fed; } 37{ }^{\circ} \mathrm{C} \text { temp (mesophilic) }\end{array}$ & $\begin{array}{l}40 \% \text { higher } \mathrm{CH}_{4} \text { production com- } \\
\text { pared to } \mathrm{AD} \text { of manure alone }\end{array}$ & Hejnfelt and Angelidaki (2009) \\
\hline FVW and abattoir wastewater (AWW) & $\begin{array}{l}\text { Single-stage ASBR; mesophilic temp; } \\
20 \text { days HRT; } 2.56 \mathrm{~g} \text { TVS/I day OLR } \\
\text { (30\%FVW:70\%AW) }\end{array}$ & $75 \%$ biogas yield improved & Bouallagui et al. (2009b) \\
\hline $\begin{array}{l}\text { FVW, fish waste, AWW and waste } \\
\text { activated sludge }\end{array}$ & $\begin{array}{l}\text { ASBR; mesophilic temp; } 10 \text { days HRT; } \\
\text { 2.46-2.51 g VS/I day OLR }\end{array}$ & $43.8-51.5 \%$ biogas yield & Bouallagui et al. (2009a) \\
\hline Olive mill wastewater with AWW & $\begin{array}{l}\text { Upflow anaerobic filter; batch; } \\
\text { mesophilic }\end{array}$ & $\begin{array}{l}44.2 \% \text { more biogas yield of the mix- } \\
\text { ture than AWW mono-digestion }\end{array}$ & Gannoun et al. (2007) \\
\hline $\begin{array}{l}\text { Cattle abattoir wastewater with FVW } \\
\text { in different proportion }\end{array}$ & $\begin{array}{l}\text { Unstirred two-staged ASBR; meso- } \\
\text { philic temp; semi-continuous fed }\end{array}$ & $\begin{array}{l}70.26 \% \text { more biogas yield and } 57.11 \% \\
\text { VS reduction of the mixture than } \\
\text { AWW mono-digestion }\end{array}$ & This study \\
\hline
\end{tabular}

2014); since co-digestion balances the required nutrients, adjusts $\mathrm{pH}$, improves buffer capacity and biodegradability, and widens the microbial strains taking part in the AD process (Esposito 2012). The AWW is composed naturally of high organics, nutrients, solids, and fats, oil, and grease (Kundu et al. 2013; Mulu and Ayenew 2015). Similarly, FVW is characterized by high-volatile solids and biodegradability (Ward et al. 2008). So the characteristics of both wastes indicate suitability for the anaerobic codigestion and they can be used as a co-substrate to one another. The alteration of both types of organic wastes to bio-energy is relevant for environmental management.

Several scholars (Table 1) also evaluated the co-digestion of abattoir solid wastes mainly poultry, swine or pig with different substrates in a single-phase AD such as cattle slurry with FVW and chicken manure (Callaghana et al. 2002); solid abattoir waste with FVW and manure (Alvarez and Lidén 2008); solid abattoir wastes with rendering plant waste (Bayr et al. 2012); solid abattoir wastes with organic fraction of municipal solid waste
(OFMSW) (Zhang and Banks 2012; Moestedt et al. 2016); solid abattoir wastes with agro-residues (PagésDíaz et al. 2014); solid pig abattoir waste with sewage sludge (Borowski and Kubacki 2015); solid cattle abattoir wastes with manure, various crops, and municipal solid waste (Pagés-Díaz et al. 2015); solid abattoir waste with pig slurry and glycerine (Rodríguez-Abalde et al. 2017); and abattoir solid waste with food waste and municipal sewage sludge (Borowski et al. 2018). Generally, all reported co-digestion of various types of solid abattoir wastes such as poultry, swine or pig solid abattoirs with other substrates gave better results than mono-digestion. However, the liquid wastes/wastewater from cattle abattoir industries was neglected and less attention was given for bio-energy recovery. Moreover, phased AD systems also give better results than the single-stage AD system for bio-energy recovery (De Vrieze et al. 2012). Since the first-stage digester serves as a shock absorber, this offers a shield to methanogens from extreme $\mathrm{pH}$ and loading rates. A better stability and biogas production with good 


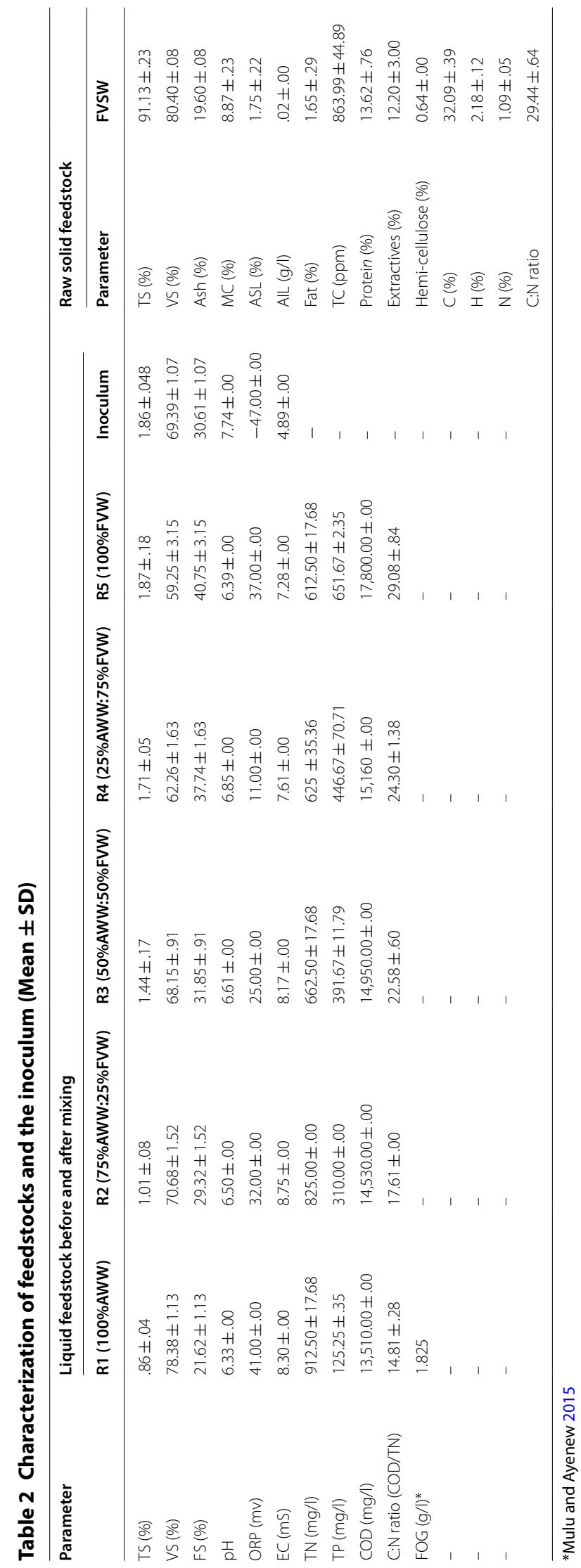


Table 3 Proportion of mixture of the substrates (AWW and FVW)

\begin{tabular}{lllll}
\hline $\begin{array}{l}\text { Representation } \\
\text { of the mixed ratio }\end{array}$ & $\begin{array}{l}\text { Proportion of substrates } \\
\text { (mixing ratio) }\end{array}$ & Type of AD & Mode of the digester & Remark \\
\hline R1 & $100 \% \mathrm{AWW}+0 \% \mathrm{FVW}$ & Mono-digestion & Two phase & Control digester \\
R2 & $75 \% \mathrm{AWW}+25 \% \mathrm{FVW}$ & Co-digestion & Two phase & Test digester \\
R3 & $50 \% \mathrm{AWW}+50 \% \mathrm{FVW}$ & Co-digestion & Two phase & Test digester \\
R4 & 25\%AWW + 75\%FVW & Co-digestion & Two phase & Test digester \\
R5 & 0\%AWW + 100\%FVW & Mono-digestion & Two phase & Control digester \\
\hline
\end{tabular}

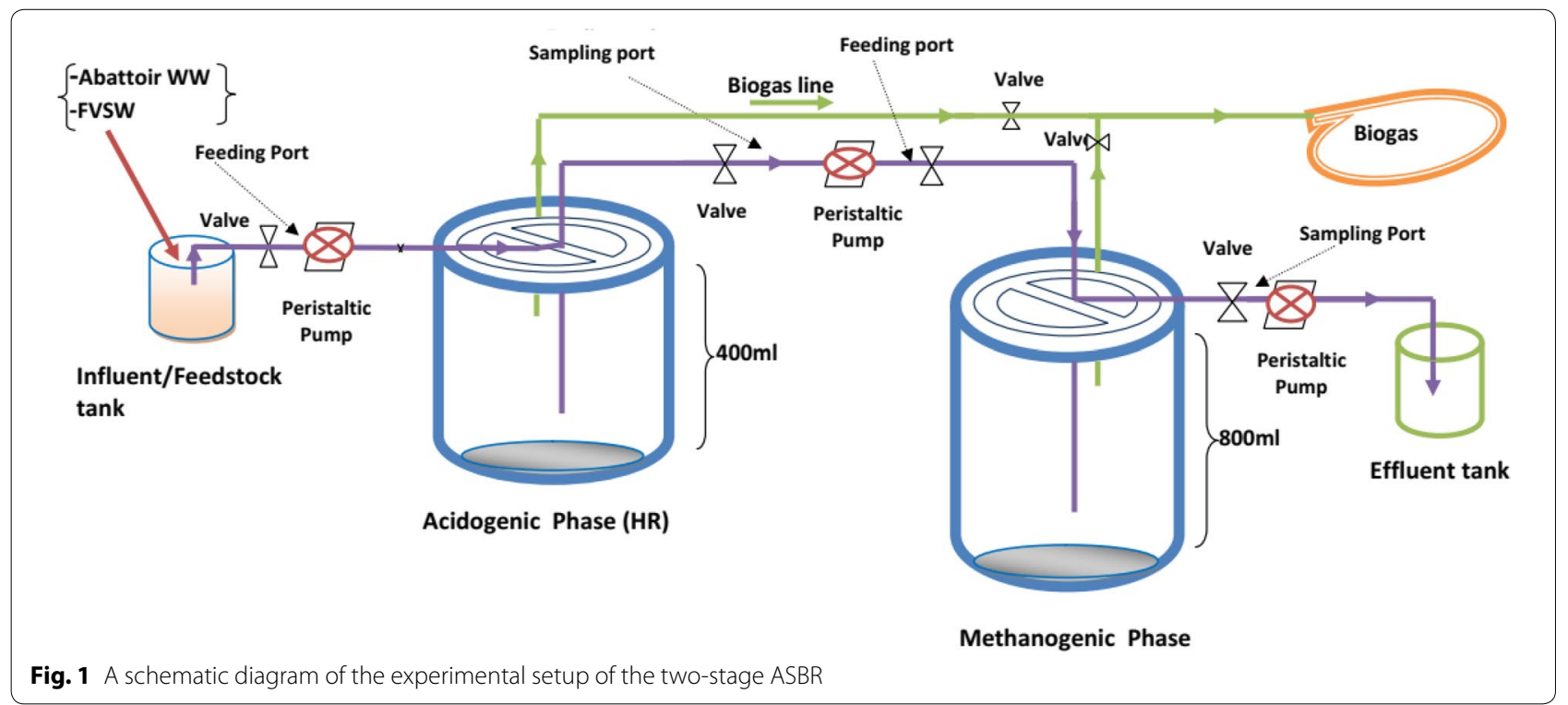

Table 4 Operating conditions and parameters during AD

\begin{tabular}{|c|c|c|c|c|c|c|c|c|}
\hline \multirow{2}{*}{$\begin{array}{l}\text { Mixing } \\
\text { ratio (R) }\end{array}$} & \multicolumn{4}{|c|}{ Acidogenic reactors(HR) } & \multicolumn{4}{|c|}{ Methanogenic reactors(MR) } \\
\hline & HRT (days) & OLR (g VS/I day) & $\begin{array}{l}\text { Flow rate } \\
\text { (ml/day) }\end{array}$ & Temperature $\left({ }^{\circ} \mathrm{C}\right)$ & HRT (days) & OLR (g VS/I d) & $\begin{array}{l}\text { Flow rate } \\
\text { (ml/day) }\end{array}$ & Temperature $\left({ }^{\circ} \mathrm{C}\right)$ \\
\hline R1 & 3 & 2.27 & 133.3 & $38 \pm 0.2$ & 15 & 0.45 & 53.3 & $38 \pm 0.2$ \\
\hline R2 & 3 & 2.38 & 133.3 & $38 \pm 0.2$ & 15 & 0.47 & 53.3 & $38 \pm 0.2$ \\
\hline R3 & 3 & 3.23 & 133.3 & $38 \pm 0.2$ & 15 & 0.64 & 53.3 & $38 \pm 0.2$ \\
\hline R4 & 3 & 3.49 & 133.3 & $38 \pm 0.2$ & 15 & 0.69 & 53.3 & $38 \pm 0.2$ \\
\hline R5 & 3 & 3.69 & 133.3 & $38 \pm 0.2$ & 15 & 0.77 & 53.3 & $38 \pm 0.2$ \\
\hline
\end{tabular}

effluent quality were obtained from the phased $\mathrm{AD}$ of FVW (Bouallagui et al. 2004). Others also obtained better COD removal from phased anaerobic co-digestion of swine and bovine AWW (Beux et al. 2007). However, studies on the anaerobic co-digestion of cattle liquid abattoir waste (AWW) with FVW as a co-substrate are limited. Therefore, so as to take the advantages of codigestion and phase separation, this work investigated the performance and stability of anaerobic co-digestion of AWW and FVW using phased anaerobic sequence batch reactor (ASBR) without mixing.

\section{Materials and methods}

\section{Sources of substrate and inoculum}

Two types of feedstocks, abattoir wastewater (AWW) and fruit-vegetable solid waste (FVW), were used for the AD that were mixed in different proportions. The AWW was collected from the municipal cattle slaughtering facility 
of Addis Ababa city, Ethiopia. It is known as Kera abattoir enterprise found in Chirkos Subcity of the city. The FVW was collected from the fruits-vegetables central market known as Atkilt-tera, located in Arada Subcity of the city, in the proportion in which they were produced.

The FVW was pre-processed to reduce the particle size and increase surface area for ease feeding and biodegradation. It includes screening to remove nonFVW objects; air-dried; and ground. The ground FVW was sieved with $0.5-\mathrm{mm}$ sieve and dissolved in distilled water $(5 \% \mathrm{w} / \mathrm{v})^{1}$ for easy pumping into the reactors. Mixtures of fresh cow dung $(15 \% \mathrm{~W} / \mathrm{V})$ and anaerobic digestate $(20 \% \mathrm{~V} / \mathrm{V})^{2}$ dissolved in distilled water were used as inoculum. Each inoculum was collected from Kera abattoir animal house and pilot-scale coffee pulp anaerobic digester at Addis Ababa University, respectively. Until feeding, all the feedstocks were stored in a refrigerator less than $4{ }^{\circ} \mathrm{C}$.

\section{Characterizes of feedstock and inoculum}

The raw fruit-vegetables solid waste (FVW), abattoir wastewater (AWW) and mixed feedstocks' (AWW and FVW) physicochemical characteristic is presented in Table 2. This table summarizes mean and standard deviation of the nature of the feed before and after mixing with one another as well as the inoculum that was used to start up the AD.

\section{Study of the influence of co-substrate addition}

The influence of fruit-vegetable solid waste (FVW) addition as a co-substrate on the performance of $\mathrm{AD}$ of abattoir wastewater (AWW) was studied by mixing the AWW with the FVW in different mixing ratios: 100\%AWW; 75\%AWW:25\%FVW; 50\%AWW:50\%FVW; 25\%AWW:75\%FVW; and 100\%FVW. These sequential mixing ratios were represented by R1; R2; R3; R4; and R5, respectively (Table 3 ). Proportioning of these feedstocks was done weekly and stored within the feedstock collection tank in less than $4{ }^{\circ} \mathrm{C}$ refrigerator until fed into the respective digesters. These mixing ratios were homogenized before feeding to the bench-scale phased/two-stage anaerobic digesters.

The two-stage AD experimental setup consisted of two paired control digesters (with mono-substrates either AWW or FVW) and three paired test digesters (with a dual substrate, a mixture of AWW and FVW). To differentiate the two-stage connected reactors, the hydrolyticacidogenic stage reactors were labeled as HR1, HR2,

\footnotetext{
$1 \% \mathrm{w} / \mathrm{v}$ : The amount by weight (mass) of a solid substrate (FVW) dissolved in $100 \mathrm{ml}$ of water solution.

$2(\% \mathrm{v} / \mathrm{v})$ The amount by volume of a semi-liquid inoculum dissolved in $100 \mathrm{ml}$ of water solution.
}

HR3, HR4, and HR5, respectively, and the corresponding methanogenic stage reactors by MR1, MR2, MR3, MR4, and MR5, respectively. The purpose of having control digesters was so as to examine the comparative advantage or disadvantage of the co-digestion for $\mathrm{AD}$ process stability and performance. The digestion of different mixing ratios was carried out in the specially constructed bench-scale experimental setups (Fig. 1) and operated at specific operation condition (Table 4). This operation was done after each bioreactor had been acclimatized separately without addition of the feeds using the inoculums. The result of this experiment was used to evaluate the influence of the addition of co-substrate (FVW) on the degradation and biogas production of the AWW. It also provided the optimum mixing ratio with the best performance measured by the highest reduction of volatile solids and biogas production.

\section{The experimental setup and operation procedures of the ASBR \\ Phased anaerobic sequence batch reactor experimental setup}

The experiment carried out in a two-stage (phase) anaerobic sequence batch reactors (ASBRs). It comprised two sequentially connected bioreactors, the first one was used for acidogenesis (HR) and the other one was for methanogenesis (MR). These two reactors were having different working (effective) volume $400 \mathrm{ml}$ and $800 \mathrm{ml}$, respectively due the fact that growth rates of the acidogenic bacteria are much higher than that of the methanogenic bacteria. Each digester was made entirely of glass and sealed by polyethylene cap. Two ports were fitted at the top of each digester one for feeding and sampling, and the other for biogas outlet from headspace of the each reactor to biogas collector bags. The schematic diagram of the experimental setup of this phased ASBR was as displayed in Fig. 1.

The bioreactors were operated in a semi-continuous mode at a total retention time of 18 days (3 days for the acidogenesis phase and 15 days for the methanogenesis phase) and constant mesophilic temperature $\left(38 \pm 0.2{ }^{\circ} \mathrm{C}\right)$ maintained via a thermostat water bath controller. Calculated amount pre-characterized monoor dual-substrates' loads (ml/days) were fed to the acidogenic reactors via a peristaltic pump driver (PD5206, S.N: 020501177). The effluents from the acidogenic reactors were used as feed to methanogenic reactors, and for characterization of the acidogenic reactors. The effluent from the methanogenic reactors was used for evaluation of the reactors' performance and stability. The produced biogas was collected in biogas collector bags that connected to each reactor. 
Table 5 Performance of acidogenic and methanogenic reactors (MR) with different mixing ratios

\begin{tabular}{|c|c|c|c|c|c|}
\hline \multirow{2}{*}{ Parameters } & \multicolumn{5}{|c|}{ Reactors with different mixing ratios } \\
\hline & HR1 & HR2 & HR3 & HR4 & HR5 \\
\hline \multicolumn{6}{|l|}{ Acidogenic reactor (HR) } \\
\hline $\mathrm{pH}$ & $7.47 \pm .09$ & $6.82 \pm .47$ & $6.41 \pm .25$ & $6.32 \pm .16$ & $6.00 \pm .3$ \\
\hline ORP (mv) & $-24.88 \pm 4.85$ & $11.00 \pm 26.38$ & $34.13 \pm 14.55$ & $39.00 \pm 9.06$ & $57.13 \pm 16.88$ \\
\hline TS (\%) & $.73 \pm .41$ & $.96 \pm .11$ & $1.35 \pm .44$ & $2.13 \pm 1.91$ & $1.53 \pm .23$ \\
\hline VS (\%) & $70.71 \pm 3.58$ & $64.14 \pm 2.47$ & $64.50 \pm 14.47$ & $57.25 \pm 1.48$ & $48.75 \pm 10.29$ \\
\hline $\mathrm{NH}_{3}(\mathrm{mg} / \mathrm{l})$ & $1726.25 \pm 139.99$ & $1432.50 \pm 185.76$ & $1273.75 \pm 316.45$ & $866.25 \pm 301.99$ & $488.75 \pm 155.97$ \\
\hline TALK $\left(\mathrm{g} \mathrm{CaCO}_{3} / \mathrm{l}\right)$ & $7.95 \pm 2.47$ & $6.82 \pm 2.36$ & $6.45 \pm 1.77$ & $5.90 \pm 1.37$ & $5.39 \pm .95$ \\
\hline TCOD (mg/l) & $9986.25 \pm 1071.63$ & $10,222.5 \pm 912.07$ & $10,175.0 \pm 1059.3$ & $10,622.5 \pm 1103.28$ & $10,791.25 \pm 1033.81$ \\
\hline \multirow[t]{2}{*}{ VFA (g/L) } & $38.71 \pm 9.88$ & $44.45 \pm 10.72$ & $44.53 \pm 9.31$ & $43.55 \pm 7.98$ & $36.94 \pm 12.43$ \\
\hline & MR1 & MR2 & MR3 & MR4 & MR5 \\
\hline \multicolumn{6}{|l|}{ Methanogenic reactor (MR) } \\
\hline $\mathrm{pH}$ & $8.02 \pm .076$ & $8.07 \pm .06$ & $7.98 \pm .08$ & $8.06 \pm .11$ & $7.99 \pm .07$ \\
\hline $\mathrm{ORP}(\mathrm{mv})$ & $-54.75 \pm 4.062$ & $-57.13 \pm 3.09$ & $-52.75 \pm 4.80$ & $-56.88 \pm 6.06$ & $-53.63 \pm 3.89$ \\
\hline TS (\%) & $.54 \pm .17$ & $.63 \pm .08$ & $1.12 \pm 1.20$ & $.78 \pm .14$ & $1.13 \pm .16$ \\
\hline VS (\%) & $70.27 \pm 12.51$ & $53.21 \pm 3.39$ & $36.97 \pm 13.65$ & $34.92 \pm 3.02$ & $39.13 \pm 11.26$ \\
\hline $\mathrm{NH}_{3}(\mathrm{mg} / \mathrm{l})$ & $1492.50 \pm 175.15$ & $1212.50 \pm 131.99$ & $901.25 \pm 108.69$ & $691.25 \pm 129.88$ & $402.50 \pm 62.51$ \\
\hline TALK $\left(\mathrm{g} \mathrm{CaCO}_{3} / \mathrm{l}\right)$ & $8.61 \pm 2.68$ & $8.77 \pm 2.47$ & $8.57 \pm 2.53$ & $8.34 \pm 2.764$ & $7.94 \pm 2.65$ \\
\hline $\mathrm{CH}_{4}(\%)$ & $56.64 \pm 1.89$ & $47.16 \pm 3.12$ & $59.95 \pm 3.66$ & $28.63 \pm 3.76$ & $31.81 \pm 2.87$ \\
\hline Biogas (ml/day) & $243.75 \pm 35.03$ & $342.50 \pm 65.63$ & $590.00 \pm 49.86$ & $331.25 \pm 37.20$ & $188.75 \pm 45.18$ \\
\hline $\mathrm{CH}_{4}(\mathrm{ml} /$ day $)$ & $138.34 \pm 22.41$ & $162.98 \pm 39.46$ & $353.86 \pm 38.46$ & $94.16 \pm 11.94$ & $59.16 \pm 10.94$ \\
\hline TCOD (mg/l) & $7212.50 \pm 2028.19$ & $6067.50 \pm 2145.61$ & $5730.00 \pm 3070.31$ & $3867.50 \pm 2625.05$ & $4227.50 \pm 3373.28$ \\
\hline TVFA ( $\left.\mathrm{g} \mathrm{CH}_{3} \mathrm{COOH} / \mathrm{l}\right)$ & $10.95 \pm 6.41$ & $11.47 \pm 3.27$ & $5.80 \pm 1.37$ & $4.91 \pm 0.43$ & $4.16 \pm 0.96$ \\
\hline VS removed (\%) & 44.7 & 53.37 & 70.23 & 63.84 & 59.84 \\
\hline $\mathrm{SMY}\left(\mathrm{mlCH}_{4} / \mathrm{g}\right.$ VS add $)$ & 20.30 & 22.84 & 36.53 & 9.00 & 5.37 \\
\hline BY (ml Biogas/g VS add) & 35.77 & 48.00 & 60.90 & 31.65 & 17.13 \\
\hline
\end{tabular}

\section{Anaerobic digestion operational parameters and procedures}

The experiment was operated in semi-continuous mode with daily feeding of the mono- and dual-substrates into the constructed phased ASBR. The basic operational parameter considered in this experiment was organic loading rate (OLR) with constant hydraulic retention times (HRT) and temperature $\left(38 \pm 0.2^{\circ} \mathrm{C}\right)$. It was investigated with five different OLRs for the acidogenesis and corresponding methanogenesis reactors (Table 4). The variation of the OLR (imparted due to the variation in mixing ratios) was achieved by increasing the volume of the solid substrate (FVW) and decreasing the liquid substrate (AWW). It was operated at a constant 18 days total HRT, of which 3 days for the acidogenesis reactor and 15 days for the methanogenesis reactors. The 18 days HRT was maintained by feeding $133.3 \mathrm{ml}$ and $53.3 \mathrm{ml}$ per day of the substrate to the acidogenic and methanogenic reactors, respectively.

The phased ASBR was operated one cycle per day for 45 days at a semi-continuous feeding mode without mixing. The total cycle length was $24 \mathrm{~h}$ made up of four stages: (i) $30 \mathrm{~min}$ (min) for feeding of the feedstock to each reactor; (ii) $21 \mathrm{~h}$ for reacting; (iii) $2 \mathrm{~h}$ for settling; and (iv) $30 \mathrm{~min}$ for drawing downing of the effluent. Both the feeding and decanting were done using a peristaltic pump driver. The same amount of effluents from each digester was removed daily to maintain the semi-continuous operation mode. The other operational conditions were maintained as specified in Table 4.

\section{Sampling and analytical methods}

Before feeding into the phased ASBRs, the homogenized inoculum and substrate were sampled. The samples were characterized in triplicate and the average values were considered as inoculum and feed characteristics. During the digestion process samples from the influent and effluent of the phased ASBRs were also collected for monitoring the process stability and performance. The sample handling and preservation procedures for physicochemical parameters were done according to the standard procedures recommended by APHA throughout the experiment (APHA 2005).

The total solids (TS), volatile solids (VS), ash content or fixed solids (FS), chemical oxygen demand (COD), and 


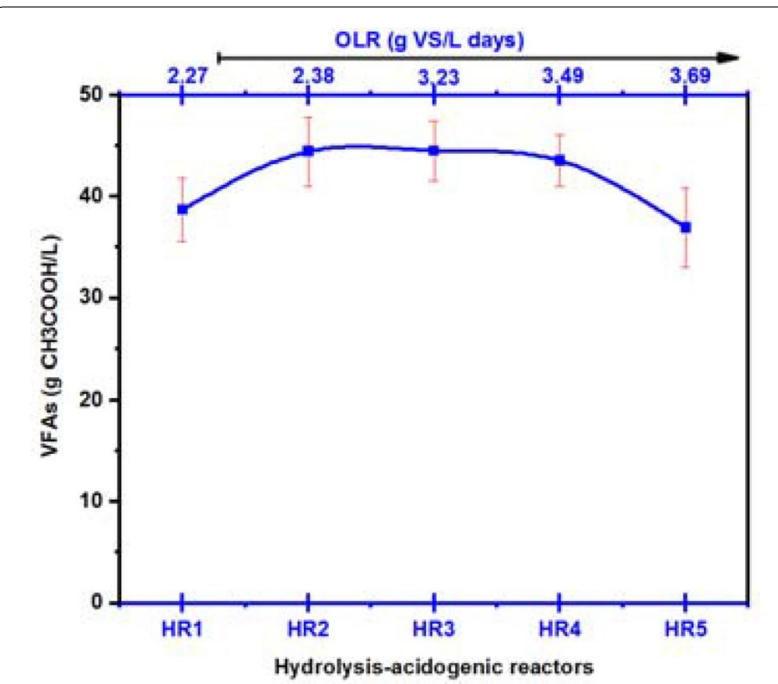

Fig. 2 Mean VFAs and standard error variations with OLR of the acidogenesis stage

total alkalinity (TAlk) of the liquid feedstocks were determined according to the Standard Methods for the Examination of Water and Wastewater (APHA 2005). The volatile fatty acids' (VFAs) concentrations were determined in terms of acetate (Ac) using simple titration after the sample had been filtered by GF Whatman filter paper $(0.45 \mu \mathrm{m})$ (Dilallo and Albertson 1961). The ammonia nitrogen $\left(\mathrm{NH}_{3}-\mathrm{N}\right)$, total nitrogen (TN), and total phosphorus (TP) were analyzed using spectrophotometer (Model DR/2400 spectrophotometer, Loveland, USA) according to the Hach procedures (Hach 2004). The $\mathrm{pH}$ and oxidation-reduction potential (ORP) were measured using pH/MV m (ModelSX711, S/N: 1115123729, China).

The pre-processed solid feedstock (FVW) was characterized for its Carbon $(\% \mathrm{C})$, hydrogen $(\% \mathrm{H})$, and nitrogen $(\% \mathrm{~N})$ contents using elemental analyzer (EA 1112 Flash CHNS/O-analyzer). The fat (\%) of the solid feedstock was analyzed by soxhlet extraction techniques using petroleum ether as extracting solvent and the protein was estimated from percentage of nitrogen as per FAO methods of feed analysis (FAO 2017). The total carbohydrate was done by colorimetric phenol sulfuric acid method using spectrophotometer (Jenway 67 series model 6705; S.N-40146) at $485 \mathrm{~nm}$ (Dubois et al. 1956). Extractives $(\% \mathrm{w} / \mathrm{w})$ were obtained by soxhlet extraction techniques, i.e., a $2.5 \mathrm{~g}$ of air-dried raw biomass was extracted using acetone and dried in oven $\left(105^{\circ} \mathrm{C}\right)$; its weight difference before and after unloading of extractives is extracted $(\% \mathrm{w} / \mathrm{w})$ (Li et al. 2004). Hemicelluloses (\%w/w) is obtained by boiling $1 \mathrm{~g}$ of dried extractive free biomass with $0.5 \mathrm{~N} \mathrm{NaOH}$ for $3.5 \mathrm{~h}$, wash sample to $\mathrm{pH} 7$ and then drying the sample at $105^{\circ} \mathrm{C}$; the difference between

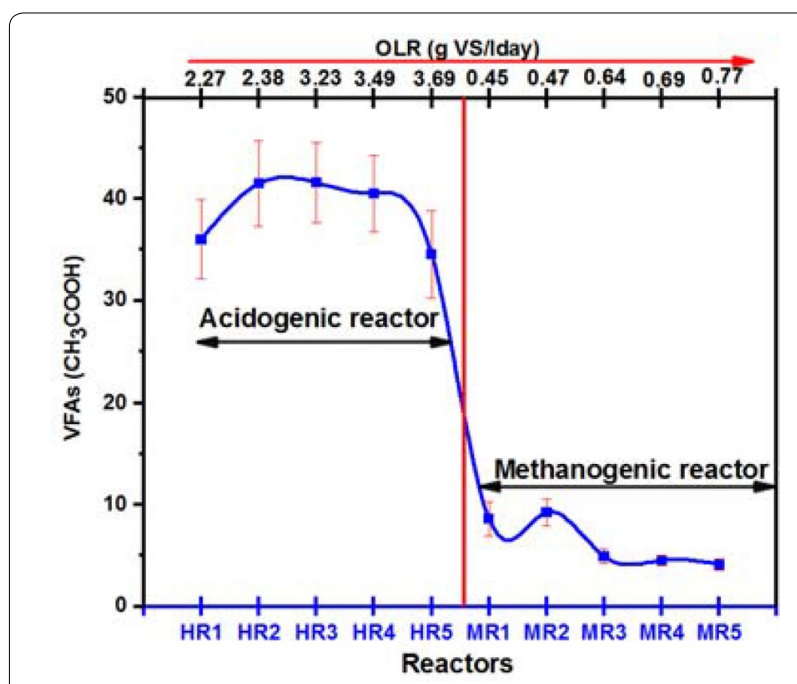

Fig. 3 The VFAs' production with different mixing ratio in two-stage ASBR

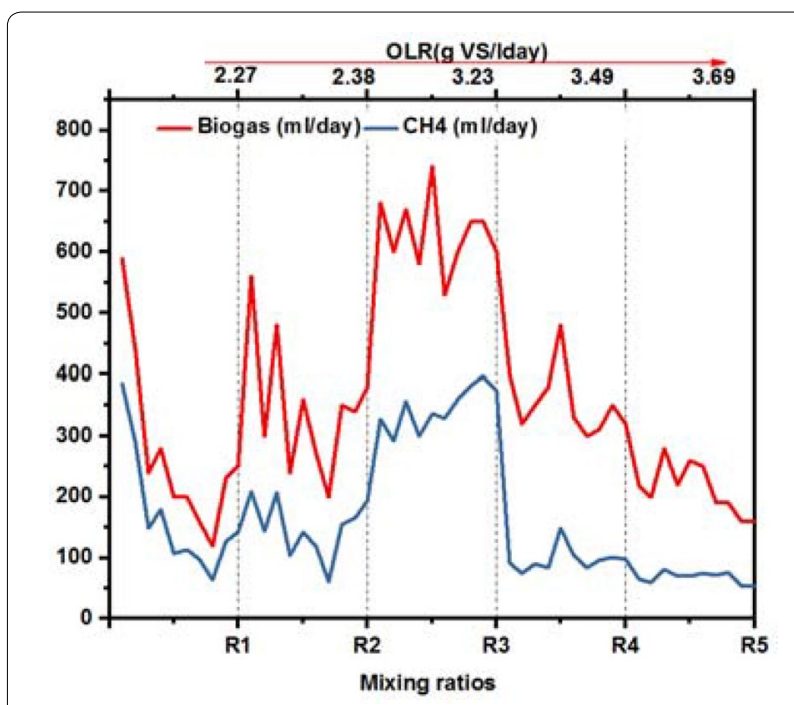

Fig. 4 Rate of biogas and methane production with different mixing ratios and OLRS

the sample weight before and after this treatment is the hemicelluloses' content (\%w/w) of dry biomass ( $\mathrm{Li}$ et al. 2004) and its extractive-free lignin was found out using NREL procedures (Sluiter et al. 2008; Templeton et al. 2010).

The composition and volume of the biogas were measured using gas analyzer (Geotechnical instrument (UK) Ltd, S/N: BM14068) and airtight syringe, respectively. The daily methane productions were calculated by multiplying the biogas volume by the corresponding methane content (Wan et al. 2011). 


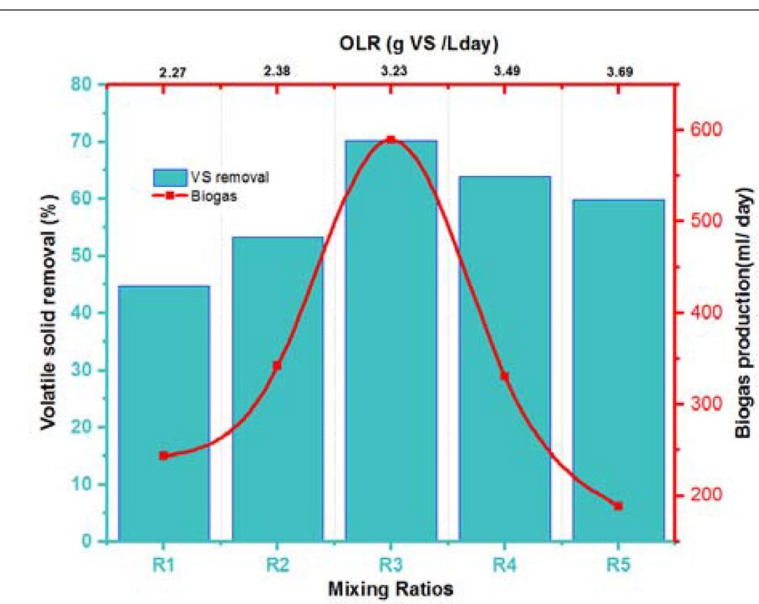

Fig. 5 Average biogas and methane production rate versus volatile solids' reduction (\%VS)

\section{Data analysis}

The statistical analysis of this result was done using statistical software, Origin 8.0 (Additional file 1).

\section{Result and discussion}

The performance and stability of the biodigestion process are highly influenced by substrate characteristic, operating parameters, and an array of different microbial groups, and their functions (Westerholm and Schnürer 2019). The average values (mean \pm SD) for the performance of acidogenic reactors (HR) and methanogenic reactors (MR) with different mixing ratios at steady state were as presented in Table 5.

\section{Volatile fatty acids in the acidogenic and methanogenic stages}

In this experiment, the production rate of the total VFAs was expressed in terms of grams of acetic acid per liter. The average production rate of total VFAs of the acidogenic reactors was ranging from 36.94 to $44.53 \mathrm{~g}$ $\mathrm{CH}_{3} \mathrm{COOH}$ per liter as displayed in Fig. 2. The values for R2 (75AWW:25FVW), R3 (50AWW:50FVW), and R4 (25AWW:75FVW) were nearly similar $\left(\sim 44 \mathrm{gCH}_{3} \mathrm{COOH} / \mathrm{L}\right)$ and operating at an OLR of 2.38, 3.23 and $3.49 \mathrm{~g} \mathrm{VS} / \mathrm{l}$ day, respectively. The VFAs was found higher for the co-digested substrates (R2, R3, and R4) than the mono-digested substrates $(\mathrm{R} 1=100 \% \mathrm{AWW}$ and $\mathrm{R} 5=100 \% \mathrm{FVW}$ ) (Fig. 2). This indicated that co-digestion improves the rate of VFAs' production that may, in turn, enhance biogas production. Further, VFA production can also be linked to C:N ratio of the substrate; the feeds with the lower $\mathrm{C}: \mathrm{N}$ ratio $(\mathrm{R} 1=14.43-15.09)$ and higher $\mathrm{C}: \mathrm{N}$ ratio ( $R 5=28.24-29.92)$ have the least VFAs' production than that with $\mathrm{C}: \mathrm{N}$ ratio in between. This also indicated that co-substrate addition also balances missed nutrients required to acidogenic bacteria.

These short-chain fatty acids are key intermediate products of the AD process which are a precursor for methanogenesis. These are mainly an important carbon source for the methanogenic bacteria; as a result, the concentration of VFAs produced in the hydrolytic-acidogenic reactors was drastically reduced in the methanogenic phase reactors (Fig. 3). Relatively, the degradation of the VFAs in the methanogenesis phase was substantially increased as the amount of co-substrate (FVW) increased (R2, R3, and R4) than the mono-digested AWW (R1). Even though having considerable production and degradations of VFAs in many of the co-digestions, the highest biogas production was observed in R3 (Fig. 4). This result indicated that only having high production of VFAs in the acidogenic phase reactor is not only warrantee to produce high biogas production in the methanogenic phase but also the methanogenic phase reactors' stability matters. Moreover, all the degraded VFAs may not be necessarily converted only into biogas but may also be converted into other anaerobic metabolites.

The inhibition of the methanogenesis process in $\mathrm{R} 1$ (100\% AWW) and R2 (75\%AWW) attributed to the substrate nature due to its high fat, oil and grease may be led to LCFAs' production. These lipid-rich substrates formed a hydrophobic layer since such lipid-rich substrates form a hydrophobic layer and destabilize the digestion process (Pereira et al. 2005). The LCFAs hinder bacteria transport and reduce contact between the substrate and the encapsulated bacteria. Besides, the problem was worsened by the inadequacy of agitation the reactors content. These situations were clearly observed in R2. On the other hand, the conversion of VFAs into biogas in $\mathrm{R} 5(100 \% \mathrm{FVW})$ may be affected due to the imbalance of nutrients ( $\mathrm{C}: \mathrm{N}$ ratio) as well as formation of untraced inhibitory substances. Generally, the result indicated that co-digestion improves biogas production compared to mono-digestions (Fig. 4).

\section{Evaluation of performance of the co-digestion process}

The performance of the co-digestion processes was evaluated in terms of gas (quality and quantity) production and volatile solid (VS) reduction. The gas production and VS reduction for the different mixing ratios were monitored and presented in Figs. 4 and 5. The average daily biogas and methane production of each mixing ratios was 243.75 and $138.34 \mathrm{ml} /$ day for $\mathrm{R} 1 ; 342.5$ and 162.98 $\mathrm{ml} /$ day for R2; 590.0 and $353.86 \mathrm{ml} /$ day for R3; 331.25 and $94.16 \mathrm{ml} /$ day for $\mathrm{R} 4 ; 188.75$ and $59.16 \mathrm{ml} /$ day for $\mathrm{R} 5$, respectively. The highest daily biogas and methane were 

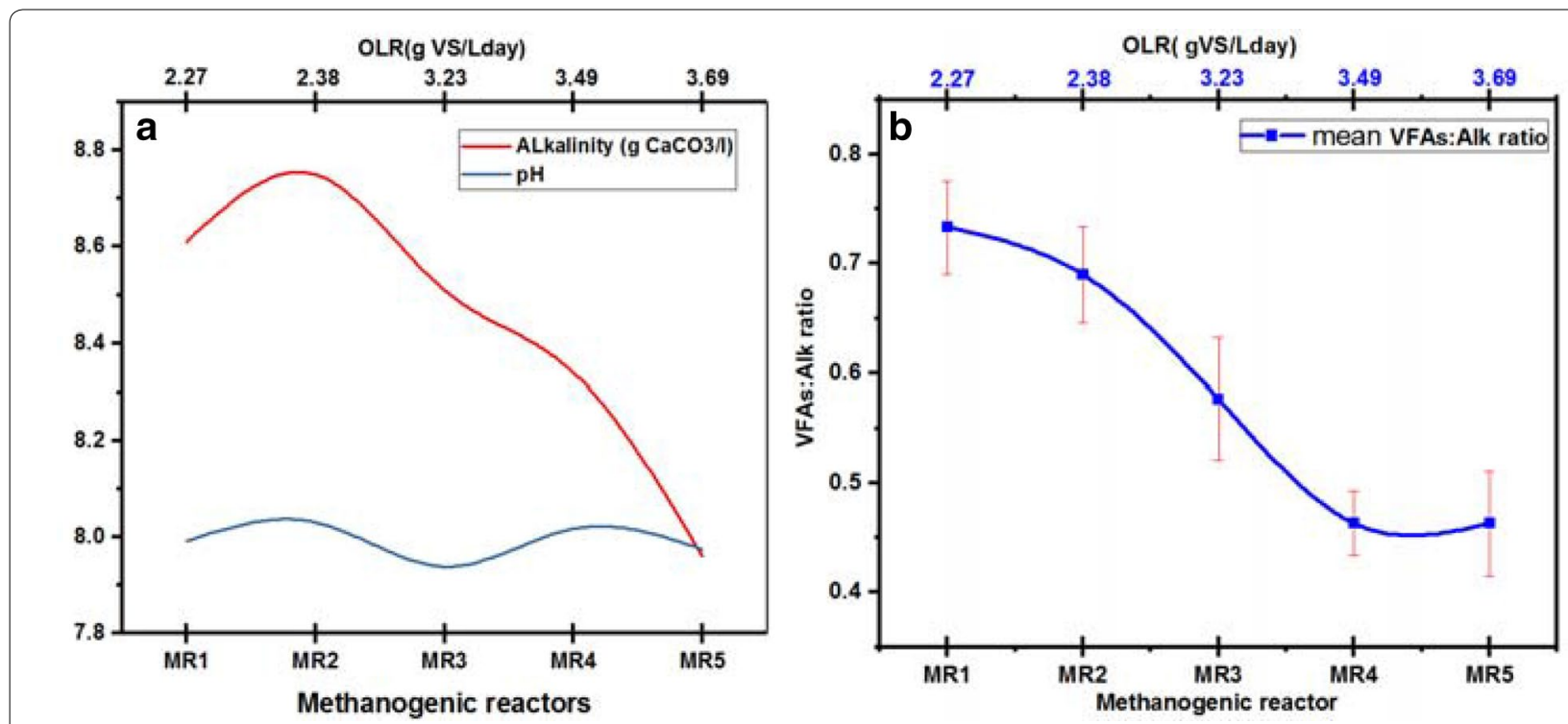

Fig. 6 Methanogenic reactors. a Average $\mathrm{pH}$ and alkalinity. b Average TVFAs:Talk ratio

obtained in R3 with an average value of 630 and $345.6 \mathrm{ml} /$ day biogas and methane, respectively. The addition of the FVW as co-substrate to AWW enhanced the biogas yield $(\mathrm{ml} / \mathrm{g}$ VS added) by $70 \%$ at the optimum mixing ratio R3 (50\%:50\%). It was operating at an OLR of $3.23 \mathrm{~g}$ VS/ ld and 22.58 of $\mathrm{C}: \mathrm{N}$ ratio. Thus, it is suggested that the 50\%AWW:50\%FVW mixing ratio is the best mixing ratio. Increasing the organic loading rate beyond $3.23 \mathrm{~g} \mathrm{VS} / \mathrm{ld}$ was resulting in a decrease in biogas quality and quantity (Fig. 4). Since increasing OLR reduces contact between the substrate and methanogens, such problem might be reduced by adequate agitation. The result indicates that the biogas production was influenced by the proportion of the co-digested substrates (AWW and FVW) fed to the digester. However, in the case of R1, the gas production had got reduced due to the highest free ammonia nitrogen (FAN) production averaged to $1726.25 \mathrm{mg} / \mathrm{l}$. It could also be influenced by the production of other inhibitory substances during the digitation process. The reduced biogas production in R4 and R5 may be attributed to either nutrient deficiency or insufficient contact between bacteria substrate (lack of agitation); consequently, inhibiting methanogenesis process.

Volatile solids' (VS) reduction is an indirect measurement of organic matter utilization in the AD process and used to monitor digester's performance. During the AD process, VS are degraded to a certain extent and converted into biogas. The degree of stabilization is often expressed as the percent reduction in VS (Appels et al. 2008). The average VS reduction of R1, R2, R3, R4, and R5 was $44.7 \%, 53.37 \%, 70.23 \%, 63.84 \%$, and $59.8 \%$, respectively. Relative to R1 (control reactor), it was improved by $57.11 \%$ after addition of the co-substrate at optimum mixing ratio (R3). The variation of VS destruction along with the biogas quality and quantity for each reactor with different mixing ratios (resulted variations in OLR) is displayed in Fig. 5. This VS reduction was found almost consistent with the biogas production rate. Again R3 was obtained with maximum VS reduction. The result indicated that R3 was the most stable reactor with a 50\%:50\% mixing ratio at $3.23 \mathrm{~g}$ VS added per liter per day OLR and 18 days HRT. VS conversion to biogas in the other reactors was hindered due to the decreased or increased amount of the co-substrate, and generation of inhibitory substances.

The biogas production rate and methane content were significantly varied among the different reactors with

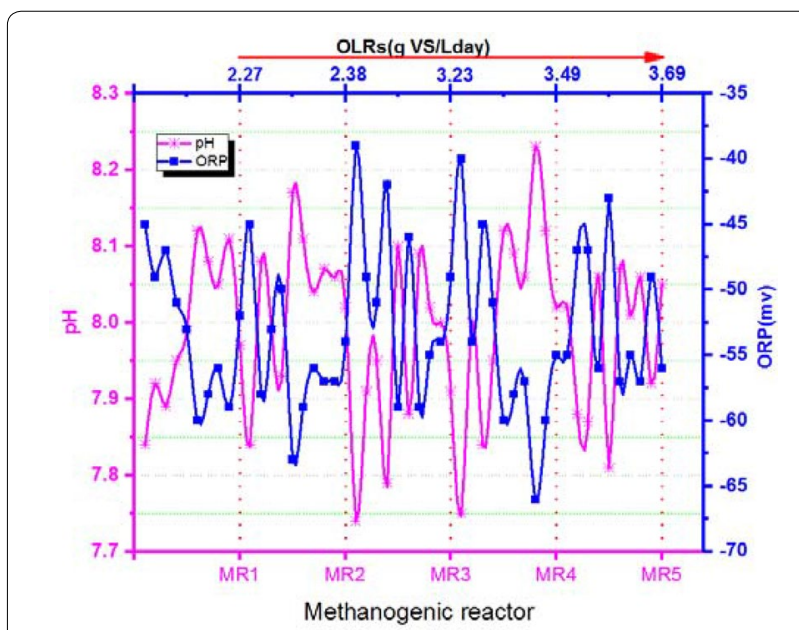

Fig. 7 Trends of $\mathrm{pH}$ and ORP in each reactor 
different mixing ratios with a $P$ value of $0.00(p<0.05)$. The main cause of the variation was due to the variation in the proportion of the co-substrate and level of FAN produced. Since, upon the progressive addition of FVW to AWW led to the improvement of $\mathrm{C}: \mathrm{N}$ ratio that in turn caused a reduction in FAN (Fig. 8).

\section{Process stability of the phased anaerobic digestion Alkalinity, and volatile acids to alkalinity ratio}

AD process stability depends on the buffering capacity of the digester contents. Alkalinity is an important parameter that measures bioreactors buffering capability to neutralize the increased acid from the acidogenesis. The total alkalinity value of the methanogenic digesters was tending $\sim 8-8.5 \mathrm{~g} \mathrm{CaCO}_{3} / \mathrm{l}$ (Fig. 6a). These high alkalinity values indicated the methanogenic digesters have a greater capacity to resist $\mathrm{pH}$ changes. Consequently, the $\mathrm{pH}$ level of each methanogenic digesters was stabilized in between 7.8 and 8.07 that reflecting a stable system. A massive $\mathrm{pH}$ change was not experienced throughout the experiment due to the good buffering capacity (Fig. 1a).

Volatile fatty acids and alkalinity together are also recognized as good indicators for the evaluation of the system stability of AD operations (Ratanatamskul et al. 2014). Combining both in a ratio is a useful tool to monitor biodigester stability much better than the $\mathrm{pH}$ monitoring alone since $\mathrm{pH}$ alone may not indicate until the problem occurs. But the TVFA:TAlk ratio can provide earlier warning information as the reactor goes to fail. Therefore, the TVFA:TAlk ratio for each reactor was regularly monitored to assess their stability as illustrated in Fig. 6b. The greater TVFA:TAlk ratio (Fig. 6b) values in the methanogenesis phase of R1 and R2 indicated the accumulations of VFAs. Consequently, it caused instability and inhibition of the methanogenesis process, since a reactor with greater than TVFA:TAlk ratio was reported as unstable (Switzenbaum et al. 1990). Generally, the ratio was slightly decreased upon a progressive increment of the co-substrate (FVW) that, in turn, contributed to the stability of the digestion process.

\section{Influence of $\mathrm{pH}$ and oxidation reduction potential (ORP) on biogas production}

The growth of methanogens is limited at less than $\mathrm{pH} 5$ and eliminated at more than $\mathrm{pH} 8.5$ (Ghaly 2000), and function at pH between 6 and 8 (Medina et al. 2014). In this study, the $\mathrm{pH}$ of the methanogen reactors remained within the working rage (7.75-8.07) for all mixing ratios. Both $\mathrm{pH}$ and oxidation-reduction potential (ORP) are important parameters in the $\mathrm{AD}$ process. The trends for each methanogenic reactors (phase) are displayed

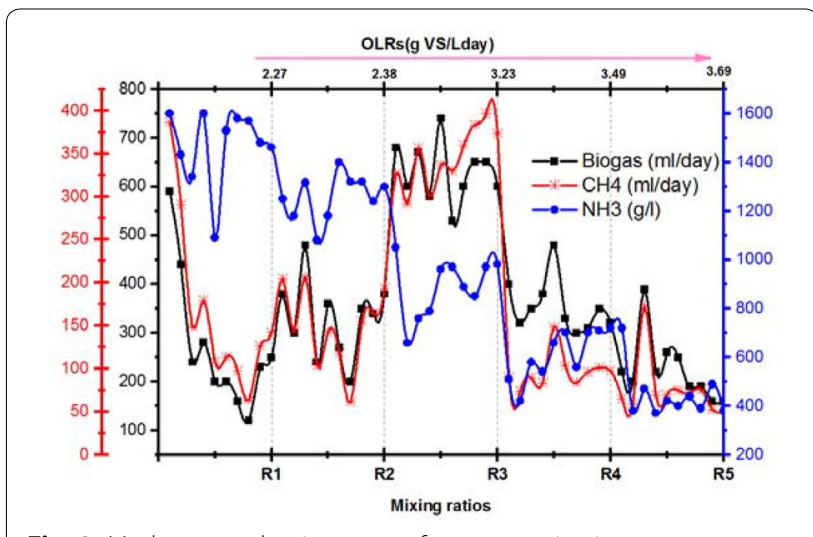

Fig. 8 Methane production versus free ammonia nitrogen

in Fig. 7. They were strongly negatively associated ( $r=-0.997^{* * *}$, at the 0.01 significant level) to each other throughout the digestion process, i.e., for every unit of increment in $\mathrm{pH}$ was resulting in a decrease in an ORP of the same reactor. In addition, the ORP of each methanogenic reactor has a negative value throughout the digestion period; this showed that the reactor condition was reducing environment (anaerobic). However, initially, all the raw feeds and the digestate in acidogenic reactors (except R1) were characterized with positive ORP value. This showed that the further degradation of the feed in the methanogenic reactor led to the release of reduced substances like methane, ammonia; after it had been digested in the methanogenic anaerobic reactors. Therefore, the negative ORP values can possible confirm the generation of methane in the bioreactors.

Statistically, the mean variation of both the $\mathrm{pH}$ and ORP was insignificant between each methanogenic reactor with different mixing ratios (OLRs) with a $P$ value of 0.184 and 0.226 (at 0.05 significant levels), respectively. This showed that both $\mathrm{pH}$ and ORP were not influential factors to cause the variation of the biogas production rate of each reactor during this experiment. It would rather be governed by other factors such as substrate proportions (organic rate), and the presence of high level of inhibitory substances such as LCFAs, $\mathrm{NH}_{3}$, etc.

\section{Effect of free ammonia nitrogen on methane production}

Free ammonia nitrogen (FAN) is very toxic to methanogenic bacteria and inhibits their growth when its concentration is within the inhibition level. Consequently, a reduced rate of biogas and methane production in $\mathrm{R} 1$ and R2 was observed due to the accumulation of a high level of FAN 1000-1800 mg/l (Fig. 8). This value falls within the inhibition zone (1000-3000 mg/l) of FAN (Chen et al. 2008; Allen et al. 2013). It is attributed to the degradation of the proteinous organics in the AWW. Moreover, 
the mean level of FAN in the methanogenic reactors with different mixing ratios significantly varied with a $P$ value 0.00 (less than 0.05 ). Those reactors which fed with a high proportion of AWW (R1 and R2) experienced a high level of FAN due to the nitrogenous nature of the AWW. It was mineralized into FAN due to the slightly alkaline nature of the bioreactors (with $\mathrm{pH} 7.75$ to 8.07). However, the FAN level in 100\%AWW (1492.50 mg/l) decreased to $1212.50 \mathrm{mg} / \mathrm{l}, 901.25 \mathrm{mg} / \mathrm{l}$, and $691.25 \mathrm{mg} / \mathrm{l}$ in R2 (75\%AWW:25\%FVW), R3 (50\% AWW:50\% FVW), and R4 (25\%AWW:75\% FVW), respectively, due to the addition the co-substrate (FVW). Since the addition of carbon-rich co-substrate (FVW) to nitrogenous substrate (AWW) led to more suitable C:N ratio, it was changed from 14.81 in R1 to $17.61,22.58$, and 24.30 in R2, R3, and R4, respectively (Table 2).

On the other hand, the reduced rate of methane production in R4 and R5 might associate with the increasing of OLRs and/or nutrient deficiency or lack of agitation. Those might lead to instability and also accompanied by other inhibitory substances generated during the digestion process.

\section{Conclusions}

The addition of FVW as co-substrate to anaerobic digestion of AWW improves its performance and process stability as compared to the mono-digestion of these individual feedstocks mainly optimum at 50\%AWW:50\%FVW mixing ratio. The improved process performance was manifested by the enhanced biogas yield (70.26\%) and VS removal (57.11\%). Besides, the improvement of process stability was pointed out by the reduction in TVFA:TAlk ratio and free ammonia (FAN) during co-digestion. On the contrary, the relative reduced biogas production in some of the reactors was due to high FAN, fat floatation, and inadequate substrate-bacteria contacts. The result of the study is important for sustainable management of both wastes. Finally, it is suggested that the microbial community diversity and effect of HRT should be studied with employing agitation for depth understanding and scale-up.

\section{Supplementary information}

Supplementary information accompanies this paper at https://doi. org/10.1186/s40643-020-00333-7.

Additional file 1: Table S1. One-way ANOVA of the effects of different mixing ratios on $\% \mathrm{CH}_{4}$ (Significant at the 0.05 level). Table S2. Pearson correlation of some variables in methanogenic reactors with different mixing ratios.

\section{Abbreviations}

AD: Anaerobic digestion; ASBR: Anaerobic sequence batch reactor; CSTR: Continuous stirred tank reactor; LCFAs: Long-chain volatile fatty acids; VFAs: Volatile fatty acids; TAlk: Total alkalinity; FVW: Fruits-vegetables solid waste; HR: Acidogenic reactor; MR: Methanogenic reactor; AWW: Abattoir wastewater; HRT: Hydraulic retention times; OLR: Organic loading rate; FAN: Free ammonia; SMY: Specific methane yield; BY: Biogas yield.

\section{Acknowledgements \\ Authors would like to thank the School of Graduate Studies, Addis Ababa University and Aksum University for financial support.}

\section{Authors' contributions}

AM: design and conduct the experiment, and draft the manuscript; SL and TA: editing and revision of the manuscript to its final version for submission. All authors read and approved the final manuscript.

\section{Funding}

The work was supported by Addis Ababa University and Aksum University.

\section{Availability of data and materials}

All data generated or analyzed during this study are included either in this research article or provided as supplementary information.

\section{Ethics approval and consent to participate}

Not applicable, the work does not include any studies with human or animals.

\section{Consent for publication}

Not applicable.

\section{Competing interests}

The authors declare that they have no competing interest.

\section{Author details}

${ }^{1}$ Centre for Environmental Science, Addis Ababa University, Addis Ababa, Ethiopia. ${ }^{2}$ Department of Chemistry, Aksum University, Axum, Ethiopia.

${ }^{3}$ School of Earth Science, Addis Ababa University, Addis Ababa, Ethiopia.

Received: 29 March 2020 Accepted: 28 July 2020

Published online: 03 August 2020

\section{References}

Allen E, Browne JD, Murphy JD (2013) Evaluation of the biomethane yield from anaerobic co-digestion of nitrogenous substrates. Environ Technol 34:2059-2068. https://doi.org/10.1080/09593330.2013.806564

Alvarez R, Lidén G (2008) Semi-continuous co-digestion of solid slaughterhouse waste, manure, and fruit and vegetable waste. Renew Energy 33:726-734. https://doi.org/10.1016/j.renene.2007.05.001

APHA (2005) Standard methods for the examination of water and wastewater. American Public Health Association/American Water Works Association/ Water Environment Federation, Washington

Appels L, Baeyens J, Degrève J, Dewil R (2008) Principles and potential of the anaerobic digestion of waste-activated sludge. Prog Energy Combust Sci 34:755-781. https://doi.org/10.1016/j.pecs.2008.06.002

Bayr S, Rantanen M, Kaparaju P, Rintala J (2012) Mesophilic and thermophilic anaerobic co-digestion of rendering plant and slaughterhouse wastes. Bioresour Technol 104:28-36. https://doi.org/10.1016/j.biort ech.2011.09.104

Beux S, Nunes E, Barana AC (2007) Effect of temperature on two-phase anaerobic reactors treating slaughterhouse wastewater. Brazilian Arch Biol Technol 50:1061-1072. https://doi.org/10.1590/S1516-8913200700 0700017

Borowski S, Kubacki P (2015) Co-digestion of pig slaughterhouse waste with sewage sludge. Waste Manag 40:119-126. https://doi.org/10.1016/j. wasman.2015.03.021

Borowski S, Boniecki P, Kubacki P, Czyżowska A (2018) Food waste co-digestion with slaughterhouse waste and sewage sludge: digestate conditioning and supernatant quality. Waste Manag 74:158-167. https://doi. org/10.1016/j.wasman.2017.12.010 
Bouallagui H, Torrijos M, Godon JJ, Moletta R, Ben Cheikh R, Touhami Y, Delgenes JP, Hamdi M (2004) Two-phases anaerobic digestion of fruit and vegetable wastes: bioreactors performance. Biochem Eng J 21:193-197. https://doi.org/10.1016/j.bej.2004.05.001

Bouallagui H, Lahdheb H, Ben Romdan E, Rachdi B, Hamdi M (2009a) Improvement of fruit and vegetable waste anaerobic digestion performance and stability with co-substrates addition. J Environ Manage 90:1844-1849. https://doi.org/10.1016/j.jenvman.2008.12.002

Bouallagui H, Rachdi B, Gannoun H, Hamdi M (2009b) Mesophilic and thermophilic anaerobic co-digestion of abattoir wastewater and fruit and vegetable waste in anaerobic sequencing batch reactors. Biodegradation 20:401-409. https://doi.org/10.1007/s10532-008-9231-1

Callaghana FJ, Wasea DAJ, Thayanithya K, Forsterb CF (2002) Continuous co-digestion of cattle slurry with fruit and vegetable wastes and chicken manure. Biomass Bioenerg 22:71-77. https://doi.org/10.1016/50961 $-9534(01) 00057-5$

Chen Y, Cheng JJ, Creamer KS (2008) Inhibition of anaerobic digestion process: a review. Bioresour Technol 99:4044-4064. https://doi.org/10.1016/j.biort ech.2007.01.057

De Vrieze J, Hennebel T, Boon N, Verstraete W (2012) Methanosarcina: the rediscovered methanogen for heavy duty biomethanation. Bioresour Technol 112:1-9. https://doi.org/10.1016/j.biortech.2012.02.079

Delforno T, Noronha MF, Sakamoto IK (2017) Microbial diversity of a full-scale UASB reactor applied to poultry slaughterhouse wastewater treatment: integration of 165 rRNA gene amplicon and shotgun metagenomic sequencing. MicrobiologyOpenogy. https://doi.org/10.1002/mbo3.443

Dilallo R, Albertson OE (1961) Volatile acids by direct titration. Water Pollut Control Federation 33:356-365

Dubois M, Gilles KA, Hamilton JK, Rebers PA, Smith F (1956) Colorimetric method for determination of sugars and related substances. Anal Chem 28:350-356. https://doi.org/10.1021/ac60111a017

Esposito G, Frunzo L, Giordano A, Liotta F, Panico A, Pirozzi F (2012) Anaerobic co-digestion of organic wastes. Rev Env Sci Biotechnol. https://doi. org/10.1007/s11157-012-9277-8

FAO (2017) Appendix Xvi : Methods of Feed Analysis. Feed Feed fish Shrimp $1-8$

Gannoun H, Ben Othman N, Bouallagui H, Moktar H (2007) Mesophilic and thermophilic anaerobic co-digestion of olive mill wastewaters and abattoir wastewaters in an upflow anaerobic filter. Ind Eng Chem Res 46:6737-6743. https://doi.org/10.1021/ie061676r

Gebreeyessus GD, Demissie BA (2013) Quantification of the potential for biogas and biogas manure from the selected fruit wastes in. Afr J Environ Sci Technol 7:1037-1043. https://doi.org/10.5897/AJEST2013.1568

Ghaly AE (2000) Effect of reseeding and $\mathrm{pH}$ control on the performance of a two-stage mesophilic anaerobic digester operating on acid cheese whey. Can Biosyst Eng/Le Genie des Biosyst au Canada 42:173-183

Hach (2004) DR/2400 Spectrophotometer procedure manual. Hach Company, Loveland

Hejnfelt A, Angelidaki I (2009) Anaerobic digestion of slaughterhouse byproducts. Biomass Bioenerg 33:1046-1054. https://doi.org/10.1016/j. biombioe.2009.03.004

Jabari L, Khelifi E, Gannoun H, Fardeau ML, Godon JJ, Hamdi M (2016) Effect of salinity and temperature on the bacterial diversity shift of anaerobic batch cultures treating abattoir wastewater. Desalin Water Treat 57:13909-13915. https://doi.org/10.1080/19443994.2015.1061950

Kundu P, Debsarkar A, Mukherjee S (2013) Treatment of slaughter house wastewater in a sequencing batch reactor: performance evaluation and biodegradation kinetics. Biomed Res Int. https://doi. org/10.1155/2013/134872

Li S, Xu S, Liu S, Yang C, Lu Q (2004) Fast pyrolysis of biomass in free-fall reactor for hydrogen-rich gas. Fuel Process Technol 85:1201-1211

Mata-Alvarez J, Dosta J, Romero-Güiza MS, Fonoll X, Peces M, Astals S (2014) A critical review on anaerobic co-digestion achievements between 2010 and 2013. Renew Sustain Energy Rev 36:412-427. https://doi. org/10.1016/j.rser.2014.04.039

Medina VF, Waisner S, Cosper S, Rodriguez G, Gilbert D, Tucker R, Macallister I, Scholze R, Burken J, Wang J (2014) Anaerobic Digestion Assessment for Contingency Base Waste Engineer Research and Development. ERDC TR-14-3
Moestedt J, Nordell E, Shakeri Yekta S, Lundgren J, Martí M, Sundberg C, Ejlertsson J, Svensson BH, Björn A (2016) Effects of trace element addition on process stability during anaerobic co-digestion of OFMSW and slaughterhouse waste. Waste Manag 47:11-20. https://doi.org/10.1016/j. wasman.2015.03.007

Mulu A, Ayenew T (2015) Characterization-of-abattoir-wastewater-and-evaluation-of-the-effectiveness-of-the-wastewater-treatment.doc. Int I Sci Eng Res 6:1026-1040

Mulu A, Ayenew T, Berhe S (2015) Impact of slaughterhouses effluent on water quality of Modjo and Akaki River in Central Ethiopia. Int I Sci Res 4:899-907

Musa MA, Idrus S, Hasfalina CM, Norsyahariati N, Daud N (2018) Effect of Organic Loading Rate on Anaerobic Digestion Performance of Mesophilic (UASB) reactor using cattle slaughterhouse wastewater as substrate. Int J Environ Res Public Health 15:1-19. https://doi.org/10.3390/ijerph1510 2220

Padilla-gasca E, López-lópez A, Gallardo-valdez J (2011) Evaluation of stability factors in the anaerobic treatment of slaughterhouse wastewater. J Bioremed Biodegrad 02:1-5. https://doi.org/10.4172/2155-6199.1000114 Pagés-Díaz J, Pereda-Reyes I, Taherzadeh MJ, Sárvári-Horváth I, Lundin M (2014) Anaerobic co-digestion of solid slaughterhouse wastes with agro-residues: synergistic and antagonistic interactions determined in batch digestion assays. Chem Eng J 245:89-98. https://doi.org/10.1016/j. cej.2014.02.008

Pagés-Díaz J, Westman J, Taherzadeh MJ, Pereda-Reyes I, Sárvári Horváth I (2015) Semi-continuous co-digestion of solid cattle slaughterhouse wastes with other waste streams: interactions within the mixtures and methanogenic community structure. Chem Eng J 273:28-36. https://doi. org/10.1016/j.cej.2015.03.049

Pereira MA, Pires OC, Mota M, Alves MM (2005) Anaerobic biodegradation of oleic and palmitic acids: evidence of mass transfer limitations caused by long chain fatty acid accumulation onto the anaerobic sludge. Biotechnol Bioeng 98:15-23. https://doi.org/10.1002/bit.20548

Ratanatamskul C, Onnum G, Yamamoto K (2014) International Biodeterioration \& Biodegradation A prototype single-stage anaerobic digester for co-digestion of food waste and sewage sludge from high-rise building for on-site biogas production. Int Biodeterior Biodegradation 95:176-180. https://doi.org/10.1016/j.ibiod.2014.06.010

Rodríguez-Abalde Á, Flotats X, Fernández B (2017) Optimization of the anaerobic co-digestion of pasteurized slaughterhouse waste, pig slurry and glycerine. Waste Manag 61:521-528. https://doi.org/10.1016/j.wasma n.2016.12.022

Sluiter A, Hames B, Ruiz R, Scarlata C, Sluiter J, Templeton D, Nrel DC (2008) Determination of Structural Carbohydrates and Lignin in Biomass Determination of Structural Carbohydrates and Lignin in Biomass. Natl Renew Energy Lab Technical Report NREL/TP-510-42618.

Stets MI, Etto RM, Galvão CW, Ayub RA, Cruz LM (2014) Microbial community and performance of slaughterhouse wastewater treatment filters. Genet Mol Res 13:4444-4455

Switzenbaum MS, Giraldo-Gomez E, Hickey RF (1990) Monitoring of the anaerobic methane fermentation process. Integr VLSI J 9:722-730. https ://doi.org/10.1016/0141-0229(90)90142-D

Templeton DW, Scarlata CJ, Sluiter JB, Wolfrum JE (2010) Compositional analysis of lignocellulosic feedstocks. 2. Method uncertainties. J Agric Food Chem 58:9054-9062. https://doi.org/10.1021/jf100807b

Tesema (2010) Overview of Addis Ababa City. 39

Wan C, Zhou Q, Fu G, LiY (2011) Semi-continuous anaerobic co-digestion of thickened waste activated sludge and fat, oil and grease. Waste Manag 31:1752-1758. https://doi.org/10.1016/j.wasman.2011.03.025

Ward AJ, Hobbs PJ, Holliman PJ, Jones DL (2008) Optimisation of the anaerobic digestion of agricultural resources. Bioresour Technol 99:7928-7940. https ://doi.org/10.1016/j.biortech.2008.02.044

Westerholm M, Schnürer A (2019) Microbial Responses to Different Operating Practices for Biogas Production Systems. In: Anaerobic Digestion. pp 1-36

Worku Z, Leta S (2017) Anaerobic digestion of slaughterhouse wastewater for methane recovery and treatability. J Sustain Green Energy 6:84-92. https ://doi.org/10.11648/j.jijse.20170605.13 
Zhang Y, Banks CJ (2012) Co-digestion of the mechanically recovered organic fraction of municipal solid waste with slaughterhouse wastes. Biochem Eng J 68:129-137. https://doi.org/10.1016/j.bej.2012.07.017

\section{Publisher's Note}

Springer Nature remains neutral with regard to jurisdictional claims in published maps and institutional affiliations.
Submit your manuscript to a SpringerOpen ${ }^{\odot}$ journal and benefit from:

- Convenient online submission

- Rigorous peer review

- Open access: articles freely available online

- High visibility within the field

- Retaining the copyright to your article

Submit your next manuscript at $\boldsymbol{\nabla}$ springeropen.com 